Jurnal Pendidikan Matematika : Judika Education

Volume 1, Nomor 2, Juli-Desember 2018

e-ISSN : 2614-6088

p-ISSN : 2620-732X

DOI: https://doi.org/10.31539/judika.v1i2.374

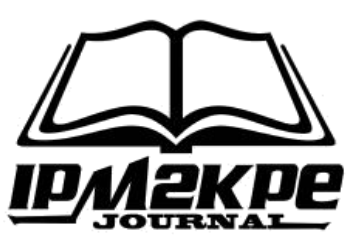

\title{
PERBEDAAN PENINGKATAN KEMAMPUAN REPRESENTASI MATEMATIS DAN SELF CONFIDENCE SISWA PADA PEMBELAJARAN BERBASIS MASALAH DAN PEMBELAJARAN BIASA
}

\author{
Cut Yuniza Eviyanti \\ STKIP Bumi Persada Lhokseumawe \\ eviyanticut@yahoo.co.id
}

\begin{abstract}
ABSTRAK
Penelitian ini bertujuan untuk mengetahui perbedaan peningkatan kemampuan representasi matematis dan self confidence siswa pada pembelajaran berbasis masalah (PBM) dan pembelajaran biasa (PB). Selain itu untuk melihat apakah terdapat interaksi antara pembelajaran dan kemampuan awal matematika (KAM) siswa terhadap peningkatan kemampuan representasi matematis siswa serta apakah peningkatan self confidence siswa. Populasi penelitian adalah seluruh siswa SMP Negeri 1 Lhokseumawe. Sampel penelitian diambil secara acak sebanyak 2 kelas berjumlah 60 orang siswa. Analisis data dilakukan dengan ANAVA Dua Jalur. Hasil penelitian, kemampuan representasi matematis siswa dapat diketahui berdasarkan nilai $\mathrm{F}$ pada faktor pembelajaran (PBM dan PB) sebesar 76,4 dengan nilai signifikansi 0,00 lebih kecil dari $\alpha 0,05$. Sedangkan nilai F berdasarkan KAM 65,8 dengan taraf signifikansi 0,00. Simpulan, Peningkatan kemampuan representasi matematis dan self confidence siswa yang diberi model PBM lebih tinggi daripada siswa yang diberi PB, dan tidak terdapat interaksi antara model pembelajaran dan KAM terhadap peningkatan kemampuan representasi matematis siswa, serta tidak terdapat interaksi antara model pembelajaran dan KAM terhadap peningkatan self confidence siswa.
\end{abstract}

Kata Kunci: Model Pembelajaran Berbasis Masalah, Pembelajaran Biasa, Representasi Matematis, Self Confidence.

\section{ABSTRACT}

This study aims to determine the differences in increasing students' mathematical representation ability and self-confidence in problem based learning (PBM) and ordinary learning $(P B)$. In addition to seeing whether there is an interaction between learning and students' initial mathematical ability (KAM) to increase students' mathematical representation ability and whether students' selfconfidence increases. The study population was all students of SMP Negeri 1 Lhokseumawe. The sample of the study was taken randomly by 2 classes totaling 60 students. Data analysis was performed with Two Path ANAVA. The results of the study, students' mathematical representation ability can be known based on the $F$ value on the learning factors (PBM and PB) of 76.4 with a significance value of 0.00 less than $\alpha 0.05$. While the $F$ value is based on KAM 65.8 with a significance level of 0.00. Conclusion, Improvement of mathematical representation ability and self confidence of students who are given PBM models 
are higher than students who are given $P B$, and there is no interaction between learning models and KAM on increasing students' mathematical representation ability, and there is no interaction between learning models and KAM towards increasing self student confidence.

Keywords: Problem Based Learning Model, Ordinary Learning, Mathematical Representation, Self Confidence.

\section{PENDAHULUAN}

Matematika sebagai salah satu mata pelajaran yang penting bagi dunia pendidikan. Hal ini dikarenakan matematika adalah ilmu dasar yang mempunyai peranan penting dalam perkembangan IPTEK. Oleh karena itu sangat diharapkan agar siswa mempunyai pemahaman yang baik tentang matematika. Pendidikan matematika memiliki kontribusi yang cukup besar pada pengembangan karakter peserta didik di sekolah. Karakterkarakter yang muncul pada peserta didik diharapkan mampu memberikan kesempatan yang luas untuk menguasai kompetensi yang diperlukan bagi kehidupan di masa kini dan masa depan. Kompetensi yang dimaksudkan merupakan kemampuan-kemampuan yang harus dimiliki oleh peserta didik.

Terdapat lima standar yang menjabarkan keterkaitan pemahaman matematika dan kompetensi matematika yang mestinya siswa ketahui dan dapat dilakukan, salah satunya adalah representasi. Zhe (2012) menyimpulkan "Mathematical representation is an instrument for students to grasp mathematical knowledge and ability". Maknanya adalah representasi matematis merupakan instrumen bagi siswa untuk memahami pengetahuan dan kemampuan matematika. Representasi juga merupakan kemampuan yang selalu diperlukan ketika orang mempelajari matematika pada semua jenjang pendidikan, maka representasi dipandang sebagai suatu komponen yang juga penting dan layak mendapatkan perhatian serius. NCTM (2000) menetapkan standar representasi yang diharapkan dapat dikuasai siswa selama pembelajaran disekolah yaitu; (1) membuat dan menggunakan representasi untuk mengenal, mencatat, atau merekam serta mengkomunikasikan ide-ide matematika. (2) memilih serta mengimplementasikan translasi antar representasi matematis untuk memecahkan masalah. (3) menggunakan representasi untuk memodelkan dan menginterpretasikan fenomena fisik, sosial, dan matematis.

Pentingnya kemampuan representasi matematis untuk dimiliki siswa sangat membantu siswa dalam memahami konsep matematis berupa gambar, simbol, dan kata-kata tertulis. Lebih lanjut, NCTM (2000) mengatakan bahwa "students in the middle grades solve many problems in which they create and use representations to organize and record their thinking about mathematical ideas". Melalui representasi matematis yang benar, siswa akan lebih mampu memahami konsep matematika karena terasa lebih konkrit dan sederhana sehingga siswa dapat menentukan strategi 
yang tepat dalam memecahkan masalah yang rumit sekalipun.

Dari beberapa pernyataan diatas, jelaslah bahwa kemampuan representasi matematis sangat penting bagi siswa untuk ditumbuh kembangkan. Akan tetapi kenyataannya, kemampuan representasi matematis ini kurang mendapatkan perhatian dari para guru untuk ditumbuhkembangkan pada siswa. Hal ini dikarenakan guru lebih berupaya agar siswa bisa menjawab soal dengan tepat tanpa meminta alasan atas jawaban siswa. Sehingga mengakibatkan siswa memiliki kemampuan representasi yang rendah.

Selain kemampuan representasi, siswa juga perlu memiliki self confidence yang baik dan hal ini juga merupakan fokus peneliti. Menurut Reddy (2014) menyimpulkan "Self confidence is critical to effective performance in the workplace and is the source of assertiveness, which is fully representing yourself to others". Maknanya adalah kepercayaan diri sangat penting dan merupakan sumber dari ketegasan, yang sepenuhnya mewakili diri terhadap orang lain. Burton \& Platts (2006) mengatakan "confidence is the ability to take appropriate and effective action in any situation, however challenging it appears to you or others". Maknanya adalah kepercayaan diri merupakan kemampuan untuk mengambil tindakan yang benar dan efektif dalam situasi apapun, meskipun terlihat menantang bagi anda atau orang lain. Sedangkan menurut Lestari \& Yudhanegara (2015) mengatakan self confidence adalah suatu sikap yakin atas kemampuan diri sendiri dan memandang diri sebagai pribadi yang utuh serta mengacu pada konsep diri. Self confidence harus ditumbuhkembangkan dalam diri siswa agar bisa memaknai proses pembelajaran matematika dalam kehidupan nyata, supaya proses pembelajaran terjadi secara maksimal, dan dapat meningkatkan kemampuan representasi siswa. Keberhasilan dan kegagalan yang dialami siswa bisa dipandang sebagai suatu pengalaman belajar. Pengalaman belajar ini akan menghasilkan self confidence siswa dalam menyelesaikan permasalahan sehingga kemampuan belajarnya akan meningkat, diperlukan self confidence yang positif dalam pembelajaran agar siswa dapat mencapai tujuan pelajarannya dan mencapai prestasi belajar yang maksimal.

Perlunya self confidence dimiliki siswa pada pembelajaran matematika ternyata tidak sesuai dengan kenyataan yang ada. Masih banyak siswa yang memiliki self confidence yang cukup buruk. Hal tersebut dapat dibuktikan oleh hasil studi TIMSS (Martyanti, 2013) yang menunjukkan bahwa pada skala internasional hanya $14 \%$ siswa memiliki self confidence yang baik terkait dengan kemampuan matematikanya. Sedangkan $45 \%$ siswa berada dalam kategori yang sedang, dan $41 \%$ sisanya berada dalam kategori yang buruk. Hal tersebut juga dialami oleh siswa di Indonesia.

Hanya 3\% siswa yang memiliki self confidence yang baik dalam pembelajaran matematika, sedangkan $52 \%$ berada dalam kategori siswa dengan self confidence yang sedang dan $45 \%$ 
sisanya berada pada kategori siswa dengan self confidence yang buruk.

$$
\text { Rendahnya tingkat }
$$

kemampuan representasi matematis serta self confidence siswa, tidak terlepas dari dan bagaimana guru mengajar serta minat dan respon siswa terhadap matematika itu sendiri. Dari hasil wawancara peneliti lakukan terhadap salah satu siswa di SMP Negeri 1 Lhokseumawe melalui perbincangan di luar kelas, diketahui bahwa pelajaran matematika merupakan pelajaran yang paling sulit dalam menyelesaikan soal khususnya terkait dengan soal-soal yang menyangkut dengan kehidupan sehari-hari. Siswa memberikan alasan bahwa soal-soal yang diajarkan oleh guru tidak sama saat belajar di kelas sehingga siswa menjadi bingung dan menimbulkan kemalasan dan tidak termotivasi untuk belajar matematika.

Hal tersebut diatas biasanya terjadi karena pembelajaran yang biasanya di lakukan oleh guru dalam kelas. Pendekatan yang digunakan oleh para guru di sekolah, umumnya merupakan pendekatan yang berpusat pada guru (teacher oriented). Guru biasanya menyampaikan materi dalam buku paket, memberikan informasi, pengertian, konsep secara langsung kepada siswa, memberikan contoh penerapan rumus matematika, mengerjakan latihan-latihan yang belum berkaitan dengan fakta real (contextual learning).

Faktor lain juga yang dapat berkontribusi terhadap kemampuan matematis siswa dan terhadap sikap belajar matematika siswa, yaitu kemampuan awal matematika (KAM) siswa, yang digolongkan kedalam kelompok tinggi, sedang dan rendah. Kemampuan awal matematika merupakan prasyarat yang seharusnya dimiliki oleh siswa supaya dapat mengikuti pelajaran dengan baik. Hal ini disebabkan materi pelajaran yang disusun secara struktur sehingga apabila seseorang mengalami kesulitan pada materi awal, maka otomatis akan mengalami kesulitan dalam mempelajari pelajaran berikutnya. Begitu juga sebaliknya, siswa yang mempunyai kemampuan awal yang tinggi dapat mengikuti pelajaran pada materi selanjutnya dengan lancar. Siswa yang memiliki KAM sedang atau rendah membutuhkan waktu dalam menerima ilmu baru dalam proses pembelajaran.

Menyadari akan pentingnya kemampuan representasi dan self confidence siswa, guru harus mengupayakan pembelajaran dengan menerapkan model-model pembelajaran yang dapat mendorong dan memotivasi siswa agar dapat melatih kemampuan representasi dan self confidence siswa. Dari hasil tersebut perlu dilakukan suatu pembelajaran yang melibatkan siswa aktif dan kreatif dalam pembelajaran yaitu dengan PBM. Tan (Rusman, 2011) mengatakan bahwa PBM merupakan penemuan terbaru pada pembelajaran karena dengan PBM kemampuan berpikir siswa dapat dioptimalisasikan melalui proses kerja kelompok atau tim yang sistematis, sehingga siswa bisa memberdayakan, menguji, mengasah juga mengembangkan kemampuan berpikirnya secara berkesinambungan. Boud \& Feletti (Rusman, 2011) mengemukakan bahwa PBM adalah penemuan terbaru yang paling signifikan dalam dunia pendidikan. Tillman (2013) menyimpulkan "Problem Based 
Learning could be described as an inquiry process that resolves questions, curiosities, doubts, and uncertainties about complex phenomena in life". Maknanya adalah PBM juga dapat menggambarkan proses memecahkan pertanyaan, keingintahuan, keraguan, dan ketidakpastian tentang fenomena yang kompleks dalam kehidupan nyata.

Berdasarkan pendapat tersebut, tampak dari pembelajaran berbasis masalah memiliki tujuan agar dapat membantu siswa dalam mengembangkan keterampilan representasi matematis juga self confidence. Pada pembelajaran berbasis masalah siswa diharuskan agar dapat melakukan pemecahan masalah-masalah yang diberikan dengan cara menggali pengetahuan atau informasi sebanyak-banyaknya. Pengalaman ini sangat dibutuhkan dalam keseharian siswa dimana berkembangnya pola pikir dan pola kerja seseorang bergantung dari bagaimana dia membelajarkan dirinya.

Berdasarkan uraian diatas, peneliti tertarik untuk melakukan penelitian guna untuk mengetahui perbedaan peningkatan kemampuan representasi matematis dan self confidence siswa pada pembelajaran berbasis masalah dan pembelajaran biasa di SMP Negeri 1 Lhokseumawe.

\section{METODE PENELITIAN}

Penelitian ini dilaksanakan di SMP Negeri 1 Lhokseumawe di kelas VII. Pelaksanaan penelitian ini dilakukan selama 5 kali pertemuan untuk masing-masing kelas sampel. Populasi penelitian ini yaitu seluruh siswa kelas VII SMPN 1
Lhokseumawe. Pemilihan siswa kelas VII sebagai populasi dalam penelitian ini didasarkan pada pertimbangan tingkat perkembangan kognitif siswa pada masa ini ada pada tahap operasional konkrit, sehingga sesuai dengan pembelajaran berbasis masalah. Pengambilan sampel dengan cara random sampling. Sampel yang diambil yaitu 2 kelas. 1 kelas sebagai kelas eksperimen yaitu kelas VII-E yang berjumlah 30 siswa dan 1 kelas sebagai kelas kontrol yaitu kelas VIIF yang berjumlah sama yakni 30 siswa. Seperti yang telah diungkapkan sebelumnya penelitian ini bertujuan untuk melihat peningkatan mengenai kemampuan representasi matematis juga self confidence antara kelompok siswa yang memperoleh model pembelajaran berbasis masalah terhadap kelompok siswa yang tidak memperoleh model pembelajaran berbasis masalah, dengan demikian penelitian ini merupakan suatu studi kuasi eksperimen dengan menggunakan disain penelitian Randomized Subjects, Pretes-Postest Control Group Design.

Pengumpulan data pada penelitian ini yakni data kemampuan representasi matematis siswa dengan menggunakan instrumen berupa tes dan data self confidence siswa dengan menggunakan instrumen berupa angket yang disusun, diukur terlebih dahulu tingkat (kriteria) validitasnya sebelum digunakan dalam pengumpulan data, dengan maksud untuk mendapatkan ketepatan data. Data yang diperoleh berasal dari skor pre-test dan skor post-test dengan cara membandingkan skor pre-test dan post-test untuk mencari peningkatan (gain) yang terjadi sesudah 
pembelajaran pada masing-masing kelompok yang dihitung dengan rumus $\mathrm{N}$-gain (gain ternormalisasi) Hake (2007:8) yaitu:

$g=\frac{S_{\text {post }}-S_{\text {pre }}}{S_{\text {maks }}-S_{\text {pre }}}$

Keterangan:

g : Gain ternormalisasi

$$
\begin{array}{ll}
S_{\text {post }} & \text { : Skor post-test } \\
S_{\text {pre }} & \text { : Skor pre-test } \\
S_{\text {maks }} & : \text { Skor maksimum }
\end{array}
$$

Hasil perhitungan nilai rata-rata $N$ gain selanjutnya diinterpretasikan dengan menggunakan klasifikasi sebagai berikut.

Tabel 1. Kriteria N-Gain

\begin{tabular}{cc}
\hline N-Gain & Interpretasi \\
\hline$g \geq 0.7$ & Tinggi \\
$0.3 \leq g<0.7$ & Sedang \\
$g<0.3$ & Rendah \\
\hline
\end{tabular}

\section{HASIL PENELITIAN}

Tes KAM diberikan untuk mengetahui kesetaraan rerata kelompok eksperimen dan kelompok kontrol, serta untuk mengelompokkan siswa berdasarkan KAM yaitu tinggi, sedang dan rendah. Soal tersebut terdiri dari 10 pilihan ganda yang diambil dari soal UN SMP. Untuk memperoleh gambaran tentang KAM siswa dilakukan perhitungan rerata dan simpangan baku.

Tabel 2. Deskripsi Nilai Tes KAM Siswa Tiap Kelas Sampel

\begin{tabular}{ccccccc}
\hline Pembelajaran & $\begin{array}{c}\text { Skor } \\
\text { Ideal }\end{array}$ & $\mathbf{N}$ & $x_{\text {min }}$ & $x_{\text {maks }}$ & $\bar{x}$ & SD \\
\cline { 1 - 5 } Kelas Eksperimen & \multirow{2}{*}{100} & 30 & 40 & 90 & 61,33 & 15,02 \\
\cline { 1 - 5 } Kelas Kontrol & & 30 & 40 & 90 & 62,33 & 15,46 \\
\hline
\end{tabular}

Berdasarkan Tabel 2. dapat diungkapkan bahwa data KAM berdasarkan sampel pembelajaran berbasis masalah dan pembelajaran biasa, keduanya memiliki kualitas
KAM yang relatif sama. Hal ini berarti bahwa memenuhi syarat untuk memberikan perlakuan berbeda pada setiap kelompok sekolah.

Tabel 3. Deskripsi Pengelompokkan Siswa Berdasarkan KAM

\begin{tabular}{cccc}
\hline \multirow{2}{*}{$\begin{array}{c}\text { Kategori } \\
\text { KAM }\end{array}$} & Statistik & \multicolumn{2}{c}{ Kelas } \\
\cline { 2 - 4 } Tinggi & $\mathrm{N}$ & Eksperimen & Kontrol \\
\cline { 2 - 4 } & Rata-rata & 83,33 & 7 \\
\cline { 2 - 4 } & Simpangan Baku (SB) & 5,16 & 82,86 \\
\hline \multirow{3}{*}{ Sedang } & $\mathrm{N}$ & 19 & 4,88 \\
\cline { 2 - 4 } & Rata-rata & 60 & 18 \\
\cline { 2 - 4 } Rendah & Simpangan Baku (SB) & 8,16 & 60,55 \\
\cline { 2 - 4 } & N & 5 & 8,73 \\
\cline { 2 - 4 } & Rata-rata & 40 & 50 \\
\cline { 2 - 4 } & Simpangan Baku (SB) & 0 & 0 \\
\hline
\end{tabular}


Rata-rata indeks Normalized berdasarkan KAM siswa dapat dilihat Gain (N-Gain) kemampuan pada Tabel 4. di bawah ini representasi matematis siswa

Tabel 4. Rata-rata $\mathbf{N}$-Gain Kemampuan Representasi Matematis Kelas Eksperimen dan Kelas Kontrol Berdasarkan KAM Siswa

\begin{tabular}{cccc}
\hline \multirow{2}{*}{ Pembelajaran } & Kemampuan Awal & \multicolumn{2}{c}{ Kemampuan Representasi Matematis } \\
\cline { 2 - 4 } & Matematika & $\overline{\boldsymbol{X}}$ & Sd \\
\hline \multirow{3}{*}{ PBM } & Tinggi & 0,815 & 0,018 \\
\cline { 2 - 4 } & Sedang & 0,714 & 0,073 \\
\cline { 2 - 4 } & Rendah & 0,602 & 0,028 \\
\hline \multirow{3}{*}{ Biasa } & Tinggi & 0,707 & 0,025 \\
& Sedang & 0,586 & 0,025 \\
\cline { 2 - 4 } & Rendah & 0,47 & 0,021 \\
\cline { 2 - 4 } & & & \\
\hline
\end{tabular}

Perbedaan rata-rata n-gain diagram di bawah ini: tersebut dijelaskan juga pada

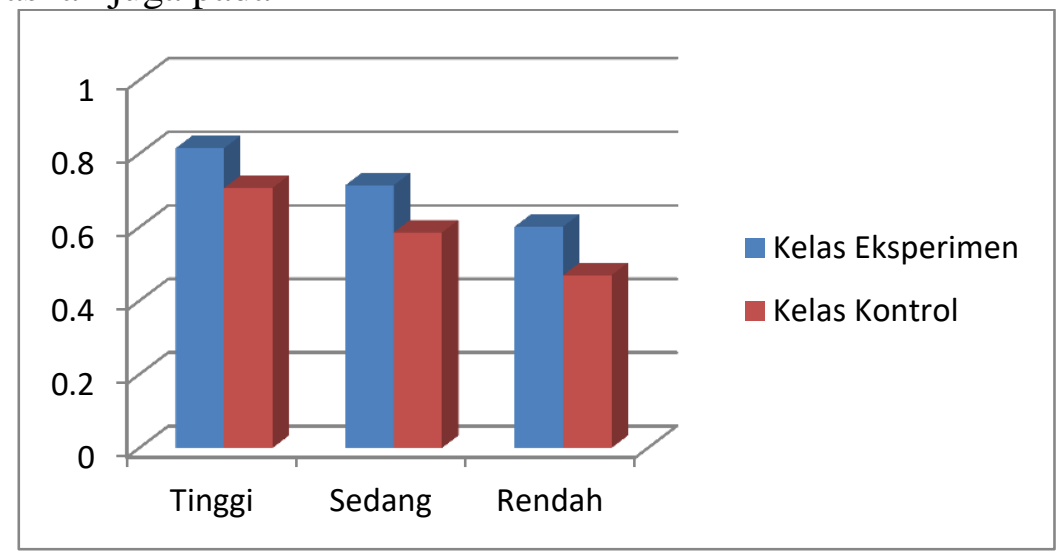

Gambar 1. Perbedaan Rata-Rata N-Gain Kelompok eksperimen dan kontrol berdasarkan kemampuan awal tinggi, sedang, dan rendah

Self confidence adalah sikap ataupun ketenangan dengan yakin akan kemampuan diri dan mampu berperilaku sesuai dengan yang diharapkan berdasarkan kemampuan yang dimiliki. Data hasil angket self confidence siswa berupa nilai $n$-gain yang diperoleh dari pemberian angket skala self confidence sebelum dan setelah pembelajaran. dengan skor maksimum adalah 80 . Nilai rata-rata n-gain merupakan gambaran peningkatan self confidence siswa berdasarkan kemampuan awal matematika (tinggi, sedang, rendah) pada pembelajaran berbasis masalah dan pembelajaran biasa. Rata-rata indeks Normalized Gain (N-Gain) self confidence siswa berdasarkan KAM siswa pada Tabel 5 di bawah ini

Tabel 5. Rata-rata N-Gain Self Confidence Kelas Eksperimen dan Kelas Kontrol Berdasarkan KAM Siswa

\begin{tabular}{llll}
\multirow{2}{*}{ Pembelajaran } & $\begin{array}{l}\text { Kemampuan Awal } \\
\text { Matematika Siswa }\end{array}$ & \multicolumn{2}{l}{ Data Skala Self Confidence } \\
\cline { 3 - 4 } & & $\bar{X}$ & $\mathrm{Sd}$ \\
\hline
\end{tabular}




\begin{tabular}{cccc}
\hline \multirow{3}{*}{ PBM } & Rendah & 0,233 & 0,016 \\
\cline { 2 - 4 } & Sedang & 0,391 & 0,060 \\
\cline { 2 - 4 } & Tinggi & 0,544 & 0,071 \\
\hline \multirow{3}{*}{ PB } & Rendah & 0,127 & 0,372 \\
\cline { 2 - 4 } & Sedang & 0,256 & 0,044 \\
\cline { 2 - 4 } & Tinggi & 0,484 & 0,528 \\
\hline
\end{tabular}

Perbedaan rata-rata n-gain di bawah ini:

tersebut dijelaskan juga pada gambar

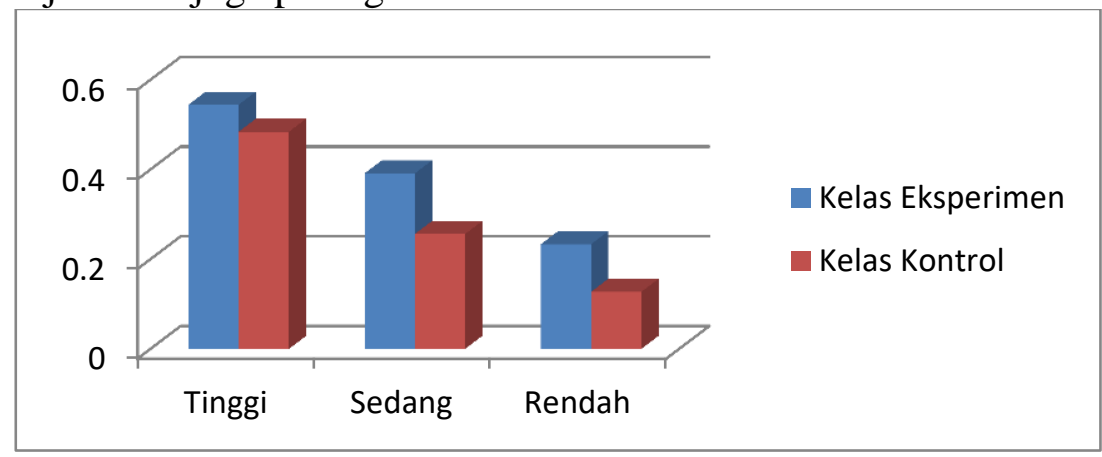

Gambar 2. Perbedaan Rata-Rata N-Gain Kelompok eksperimen dan kontrol berdasarkan kemampuan awal, tinggi, sedang, dan rendah

\section{PEMBAHASAN}

Berdasarkan perhitungan uji ANAVA dua jalur $N$-gain kemampuan representasi matematis dapat diketahui bahwa nilai $\mathrm{F}$ pada faktor pembelajaran (PBM dan $\mathrm{PB}$ ) sebesar 76,4 dengan nilai signifikansi 0,00 lebih kecil dari taraf signifikansi 0,05 . Sedangkan nilai $\mathrm{F}$ berdasarkan KAM 65,8 dengan taraf signifikansi 0,00 , sehingga $\mathrm{H}_{0}$ ditolak. Dengan kata lain, terdapat peningkatan kemampuan representasi matematis antara siswa yang diberi pembelajaran berbasis masalah (PBM) dibandingkan dengan siswa yang diberi pembelajaran biasa (PB). Dengan demikian dapat disimpulkan bahwa peningkatan kemampuan representasi matematis siswa yang menggunakan pembelajaran berbasis masalah (PBM) lebih tinggi dibandingkan siswa yang pembelajarannya secara biasa (PB). Hal ini menunjukkan bahwa pembelajaran berbasis masalah memiliki pengaruh yang lebih besar dalam mengembangkan kemampuan representasi. Ini disebabkan beberapa hal, salah satunya adalah karakteristik pembelajaran berbasis masalah yaitu pembelajaran yang menuntut siswa untuk mencari tahu dan menemukan sendiri serta mengkonstruksi pengetahuannya sendiri dengan menggunakan beberapa informasi yang diperoleh atau pengalaman belajar yang pernah diperoleh sebelumnya. Hal tersebut menjadikan pembelajaran berbasis masalah menjadi lebih bermakna. Hal yang sama juga dijelaskan oleh hasil penelitian Damanik (2013) menunjukkan bahwa kemampuan reprsentasi matematis yang diajarkan menggunakan model pembelajaran berbasis masalah lebih baik dari pada siswa yang diajarkan dengan model pembelajaran konvensional. Hasil penelitian peneliti dan Damanik menyatakan bahwa model pembelajaran berbasis masalah sangat baik untuk diterapkan dan sangat bagus untuk referensi bagi guru 
matematis khususnya. Selain itu, hal yang sama juga dijelaskan oleh hasil penelitian Surya, et al., (2013) yang menunjukkan bahwa penndekatan kontekstual dapat meningkatkan kemampuan representasi matematis pada siswa dengan kategori awal tinggi, menengah, dan rendah dibandingkan dengan pendekatan konvensional. Selain itu hasil penelitian Syahputra \& Surya (2017) juga menunjukkan bahwa model belajar yang konkret (model pembelajaran berbasis pemecahan masalah) dapat diimplementasikan untuk meningkatkan kemampuan berpikir siswa tingkat tinggi dalam menyelesaikannya masalah matematika. Syahputra (2013) juga mengungkapkan pembelajaran berbasis masalah dapat meningkatkan kemampuan pemecahan masalah matematika, cara berpikir divergen, dan meningkatkan kreativitas matematika siswa.

Untuk faktor pembelajaran yang berhubungan dengan kemampuan matematika siswa diperoleh nilai $F$ sebesar 0,277 dengan nilai signifikansi sebesar 0,759 lebih besar dari taraf signifikansi 0,05 , sehingga $\mathrm{H}_{0}$ diterima. Maka dapat disimpulkan bahwa tidak terdapat interaksi antara pembelajaran dan kemampuan awal siswa (tinggi, sedang dan rendah) terhadap peningkatan kemampuan representasi matematis siswa. Dengan kata lain, peningkatan kemampuan representasi matematis siswa disebabkan oleh perbedaan pembelajaran yang diberikan bukan dikarenakan kemampuan matematika siswa. Secara grafik, interaksi tersebut dapat dilihat pada gambar 3 .

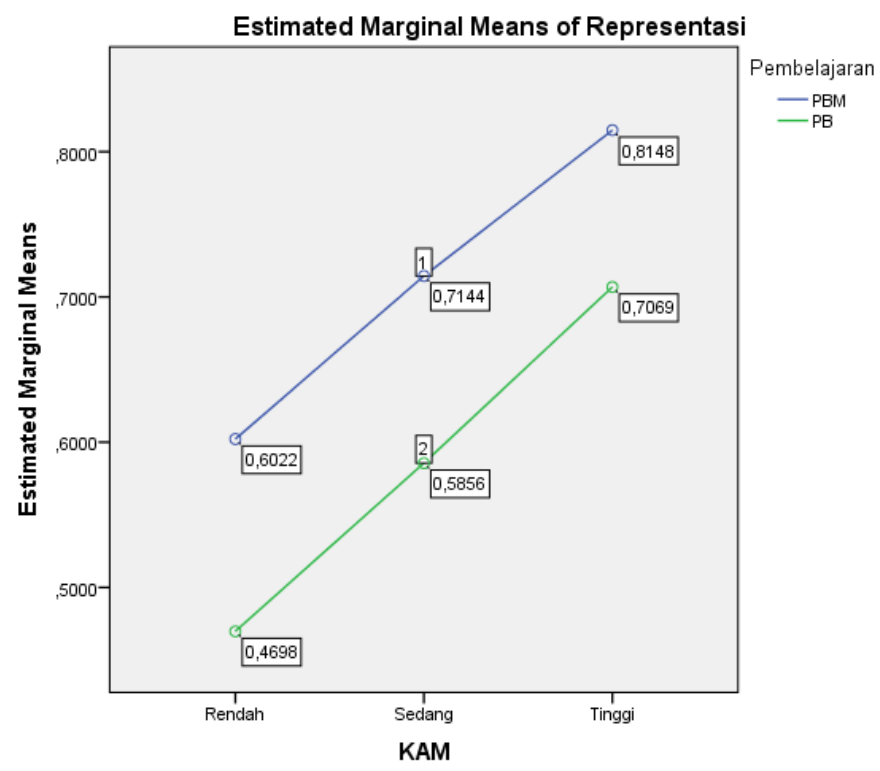

Gambar 3. Interaksi antara Faktor Pembelajaran dan Kemampuan Awal Matematika Siswa terhadap Peningkatan Kemampuan Representasi Matematis Siswa

Berdasarkan gambar 3. di atas terlihat bahwa tidak terdapat interaksi antara pembelajaran dan kemampuan awal matematika siswa (tinggi, sedang dan rendah) terhadap peningkatan kemampuan representasi matematis siswa. Dalam hal ini dapat terlihat bahwa selisih peningkatan kemampuan representasi matematis antara PBM dengan PB pada siswa 
kelompok tinggi, sedang, maupun rendah tidak berbeda secara signifikan. Hal ini juga dapat diartikan bahwa interaksi pendekatan pembelajaran dengan KAM siswa tidak berpengaruh secara bersamasama dalam peningkatan kemampuan representasi matematis. Perbedaan peningkatan kemampuan representasi matematis disebabkan oleh perbedaan pendekatan pembelajaran yang digunakan bukan karena KAM siswa.

Pengujian hipotesis statistik kedua dilakukan untuk menguji apakah peningkatan self confidence siswa pada kelas eksperimen lebih tinggi daripada kelas kontrol. Sedangkan hipotesis statistik keempat untuk melihat interaksi antara faktor pembelajaran dan KAM terhadap self confidence siswa. Pengujian dilakukan dengan ANAVA dua jalur. Hasil pengujian menunjukkan bahwa kelompok data $N$-gain self confidence beasal dari populasi yang berdistribusi normal dengan varians masing-masing pasangan kelompok data homogen, maka selanjutnya dilakukan analisis statistik ANAVA dua jalur menggunakan SPSS 20.

Berdasarkan perhitungan uji ANAVA dua jalur gain ternormalisasi self confidence diketahui bahwa nilai $\mathrm{F}$ pada faktor pembelajaran (PBM dan PB) sebesar 34,835 dengan nilai signifikansi 0,00 lebih kecil dari taraf signifikansi 0,05. Sedangkan nilai F berdasarkan KAM 103,25 dengan taraf signifikansi 0,00 , sehingga $\mathrm{H}_{0}$ ditolak. Dengan kata lain, terdapat peningkatan self confidence antara siswa yang diberi pembelajaran berbasis masalah (PBM) dibandingkan dengan siswa yang diberi pembelajaran biasa (PB). Dengan demikian dapat disimpulkan bahwa peningkatan self confidence siswa yang menggunakan pembelajaran berbasis masalah (PBM) lebih tinggi dibandingkan siswa yang pembelajarannya secara biasa (PB). Terlihat juga bahwa untuk faktor pembelajaran yang berhubungan dengan kemampuan matematika siswa diperoleh nilai $F$ sebesar 2,122 dengan nilai signifikansi sebesar 0,130 lebih besar dari taraf signifikansi yaitu 0,05 , sehingga $\mathrm{H}_{0}$ diterima. Maka dapat disimpulkan bahwa tidak terdapat interaksi antara pembelajaran dan kemampuan awal siswa (tinggi, sedang dan rendah) terhadap peningkatan self confidence siswa. Secara grafik, interaksi antara model pembelajaran dan kemampuan awal terhadap peningkatan self confidence siswa tersebut dapat dilihat pada gambar.

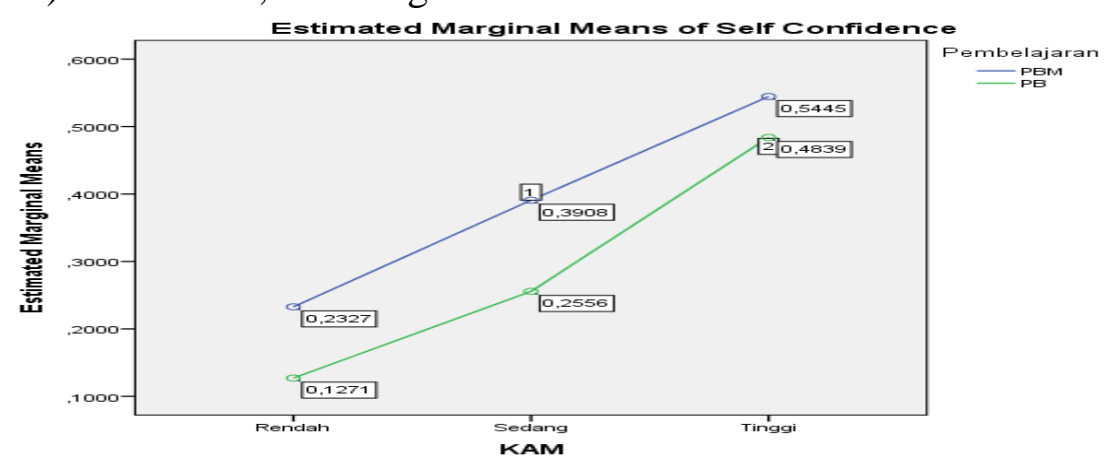

Gambar 4. Interaksi antara Faktor Pembelajaran dan Kemampuan Awal Matematika Siswa terhadap Peningkatan Self Confidence Siswa 
Berdasarkan gambar 4. di atas terlihat bahwa tidak terdapat interaksi antara pembelajaran dan kemampuan awal matematika siswa (tinggi, sedang dan rendah) terhadap peningkatan self confidence siswa. Dalam hal ini terlihat bahwa perbedaan peningkatan self confidence siswa antara PBM dengan PB pada siswa kelompok tinggi, sedang, maupun rendah tidak berbeda secara signifikan. Hal ini juga dapat dimaksudkan bahwa interaksi pendekatan pembelajaran dengan KAM siswa tidak berpengaruh secara bersama-sama terhadap peningkatan self confidence siswa.

\section{KESIMPULAN}

Berdasarkan hasil analisis data penelitian tentang kemampuan representasi matematis dan selfconfidence siswa yang diajar dengan model PBM dan PB, maka diperoleh beberapa kesimpulan yakni : Peningkatan kemampuan representasi matematis siswa yang memperoleh PBM (kelompok eksperimen) lebih tinggi daripada siswa yang memperoleh PB (kelompok kontrol), peningkatan self confidence siswa yang memperoleh PBM (kelompok eksperimen) lebih tinggi daripada siswa yang memperoleh PB (kelompok kontrol), tidak terdapat interaksi antara model pembelajaran dan KAM terhadap peningkatan kemampuan representasi matematis siswa serta tidak terdapat interaksi antara model pembelajaran dan KAM terhadap peningkatan self confidence siswa.

\section{DAFTAR PUSTAKA}

Burton, K. \& Platts, B. (2006). Building Confidence For Dummies. Inggris: John Wiley and Sons.

Damanik, R, S. (2013). Pengaruh Pembelajaran Berbasis Masalah Terhadap

Kemampuan Representasi dan Minat Belajar Matematika Siswa SMK Negeri 11 Medan. Masters Thesis UNIMED (tidak diterbitkan).

Hake, R. (2007). Design-Based Research In Physics Education: A Review in A.E. Kelly, R.A. Lesh, \& J.Y. Baek, eds. (in press), Handbook of Design Research Methods in Mathematics, Science, and Technology Education. Erlbaum.

Lestari, K. E. \& Yudhanegara, M. R. (2015). Penelitian Pendidikan Matematika. Bandung: PT Refika Aditama.

Martyanti, A. (2013). Membangun Self Confidence Siswa Dalam Pembelajaran Matematika Dengan Pendekatan Problem Solving. UNY: Yogyakarta.

NCTM. (2000). Principles and Standards for School Mathematics. ISBN 0-87353480-8. United States of America: The National Council of Teachers of Mathematics, Inc.

Reddy, M. M. (2014). A Study of Self Confidence in Relation to Achievement Motivation of D.ed Students. Global Journal for Research Analysis. Tirupati: GJRA. 3(8) 
Rusman. (2011). Model-Model PembelajaranMengembangka n Profesionalisme Guru. Bandung: Raja Grafindo.

Surya, E. (2013). Improving of Junior High School Visual Thinking Representation Ability in Mathematical Problem Solving by CTL. IndoMS.J.M.E. 4(1)

Syahputra, E. (2013). Pembelajaran Berbasis Masalah dan Kreativitas Siswa dalam Pendidikan Matematika. Medan: UNIMED. Prosiding Seminar Nasional Matematika dan Terapan 2013 (SiManTap4). 2(1)

Syahputra, E. \& Surya, E. (2017). The Development of Learning Model Based on Problem Solving to Construct HighOrder Thinking Skill on the Learning Mathematics of 11th Grade in SMA/MA. Journal of Education and Practice. $8(6)$

Tillman, D. (2013). Implications of Problem Based Learning (PBL) in Elementary Schools Upon the K-12 Engineering Education Pipeline. ATLANTA. The University of Texas at El Paso (UTEP).

Zhe, L. (2012). Survey of Primary Students' Mathematical Representation Status and Study on The Teaching Model of Mathematical Representation. Cina: Journal of Mathematics education. $5(1)$ 